\title{
Psychology of computerization as a step towards the development of cyberpsychology
}

\author{
Aleksandr Ye.Voiskounsky \\ Lomonosov Moscow State University, Moscow, Russia
}

\begin{abstract}
The need for the psychology of computerization as a separate psychological discipline was suggested by Prof. Oleg K. Tikhomirov in mid-1980s. First he tried to initiate this discipline as a by-product of his experiments in the psychology of thinking, which formed the basis of the Personal Meanings Theory of Thinking, to be formulated later; soon Tikhomirov enlarged the field of the psychology of computerization. The aims of the new discipline were to study (1) the differences between human mental activity and the operations performed by computers that constitute the key elements of artificial intelligence systems, and (2) the impact of information technology on the human psyche. With the passage of several decades, the first aim partly lost its importance, while the second acquired a high degree of significance. In the paper it is argued that Tikhomirov's suggestion that the psychological consequences of computerization be studied happened to germinate into the development of cyberpsychology (the psychology of the Internet) in Russia.
\end{abstract}

Keywords: psychology of thinking, personal meanings theory, cognition, computerization, Internet, cyberpsychology, artificial intelligence

\section{Psychology of computerization: its background and development}

Among the areas of academic work that Oleg K. Tikhomirov focused on, there was a field which he himself called "the psychology of computerization". This title can be traced in his works starting in the mid-1980s (Tikhomirov, Babanin, 1986), though in fact Tikhomirov has advanced this field starting in mid-1960s. Indeed, the first volumes that were collected, edited and partly authored by Tikhomirov which were fully devoted to pioneering the psychological study of the use of computers (needless to say, exclusively mainframe computers were available at that time) and human-computer interaction, initiated by Tikhomirov, were published in early 1970s (Chelovek i komputer, 1972; Chelovek i EVM, 1973). All in all, during a quarter of a century Tikhomirov initiated work on over ten published books (monographs, collective monographs and edited volumes) in Russian on various themes related to the psychology of computerization. 
The psychology of computerization has been first referred to as a by-product of theoretical and empirical studies in the psychology of thinking, which was carried out by Tikhomirov and his disciples and colleagues. But since the late 1980 s, it was becoming more and more obvious that any studies of the impact of information and communication technologies on the human psyche that were carried out by qualified scholars, need to be considered a priority and thus are worth of a special title within the range of psychological disciplines. The special title chosen by Tikhomirov was the 'psychology of computerization'; now, after about three decades have passed, we have to admit that this title has not been widely used and has proved to be impractical; the reasons will be discussed later in this paper.

In the current section of the paper we are going to reconstruct the reasons for providing a special title to the scholarly work in this field as early as in 1980s (Tikhomirov, Babanin, 1986). As has already been mentioned, the reasons came to light much earlier: Tikhomirov's initial impulse for carrying out studies related to the psychology of computerization goes back to 1960s, when he started his life-long project of developing the original psychological theory of thinking: the "personal meanings theory" (Tikhomirov, 1969). Prior to starting his own study, Tikhomirov, as a young researcher, browsed and thoroughly studied scientific literature in order to gain full knowledge of the academic sources on the theme. He found that the newest published materials were at that time describing recently developed computer models which were developed to simulate human thinking processes while solving puzzles, learning, controlling complex processes, playing intellectual games, recognizing simple objects, comprehending and translating texts, creating music, performing mathematical and logical reasoning, etc.

Indeed, parallel to the advancement of computers that has taken place since late 1940s (especially in the 1950s and later), several shockingly new theories have been developed - in particular, cybernetics (Ashby, 1956; Wiener, 1948), game theory (Neumann, Morgenstern, 1944), information theory (Shannon, Weaver, 1949), systems theory (Bertalanffy, 1950), formalized linguistic theory (Chomsky, 1957), and artificial intelligence (Computers and Thought, 1963; McCarthy et al., 1955; Newell, Shaw, \& Simon, 1958). The rapid escalation of computer productiveness in various fields of practice, intertwined with the fascinating new theories mentioned above, seemed to promise that computer models of human thought, digital models of visual perception or language learning, as well as simulations of the most broad psychological constructs such as conscience, creativity, or personality, could be easily enough realized, given the existing and would-be (in the closest future) hardware and software. Starting in the mid-1950s, ideas of this type emerged under a provocative and promising name, 'artificial intelligence', and dominated in academic literature, including respectful psychological journals and monographs. Elements of human-like behavior were universally believed to be among the most desirable objects of simulation and modeling supported by the use of information or system-theory models and calculations based on various mathematical, logical and cybernetic methods plus elaborated psychological data (Computers and Thought, 1963).

Tikhomirov was fully aware of the new theoretical paradigms and used them in his work whenever possible. He partly shared the critical view that was held by 
the proponents of new theories towards more old-fashioned views, even when they were expressed in a slightly modernized way. For example, like Noam Chomsky, in 1959 he reviewed and was critical of B.F. Skinner's book Verbal Behavior (Chomsky, 1959; Tikhomirov, 1959). To be fair, Chomsky's review was more extensive and more widely cited. Tikhomirov expressed a life-long interest in the advances in artificial intelligence and never rejected the usefulness of the studies which have evolved into well-grounded research fields such as "human information processing” (Lindsay, Norman, 1972; Miller, Galanter, \& Pribram, 1960; Newell, Simon, 1972) and later into cognitive psychology. Tikhomirov's point was that there was a psychology of thinking: the newborn theories showed significantly less progress in this field compared to the studies related to other cognitive processes, such as, for example, visual perception or working memory models. The application of the new theories to thought processes often resulted in foresights and promises, it was believed that human beings should be excluded from hypothetical problem solving procedures and decision making: that "ideal-seeking purposeful systems" (Ackoff, Emery, 1972) would do better and make fewer mistakes. We can say four or five decades later that Tikhomirov, as a psychologist and someone with his own view of the perspectives, had views that were more correct and ultimately prescient, than those of the many so-called visionaries. Tikhomirov stood against what he called the "replacement" and "substitution" of humans; he called information processing in thinking "informational theories" and insisted that it is "necessary to contrast the psychological theory of thought with the informational theory of thought. "This latter theory ... is often interpreted as a description of thought at the elementary level of information-processing" (Tikhomirov, 1974, p. 364, italics made by Tikhomirov).

Tikhomirov's ideas regarding the psychology of computerization embrace two main points: first, a detailed sophisticated comparison of inherently human thinking patterns to the operation of numerous artificial intelligence systems and models, and second, an investigation of the specific impact of computers (or more broadly - information and communication technologies) on human psychological processes and functions (Tikhomirov, Babanin, 1986). Over the course of the intervening years, the first point which was extremely important for Tikhomirov, has nevertheless been sidelined and has partly lost its significance, while the second point has gained genuine and globally recognized importance (Voiskounsky, 2008a).

The aforementioned first point, i.e. comparisons between human and artificial operations, is worth mentioning in light of some historic details. During the late 1950 s and 1960s, so-called heuristic programming (as a research program within the artificial intelligence field) was believed to be a promising methodology to effectively simulate the processes of reflection, thinking, and decision making; the perspectives of a particular heuristic programming system, named General Problem Solver (GPS), were enthusiastically discussed (Newell et al., 1958; Computers and Thought, 1963). Soon enough, nevertheless, it became evident that while GPS was a fairly good solver of puzzles, logical and high-school mathematical tasks, it was impotent when it came to dealing with real-world problems.

Once the field of artificial intelligence (AI) got a strong impulse, it started to accelerate from the mid-1950s in several directions, until its lavish financing has 
been significantly reduced (mostly due to the end of the "cold war", but partly due to the lack of novel breakthroughs) by the last decade of the $20^{\text {th }}$ century. It was said that "the AI winter" had started. The modern supercomputers perform nowadays rapid calculations on a platform of 'brute force' algorithms, and when combined with sophisticated AI methods, they may often suggest reasonable realtime solutions to real-life problems. It is enough to mention several overwhelming achievements such as Deep Blue's victory against chess prodigy and champion Gary Kasparov in 1997, or the result of a question answering system, Watson, which outscored the best egghead erudites in the TV quiz show "Jeopardy!" One should not forget numerous futuristic movies on the theme; some of them meet very high standards, including the brutal "2001: A Space Odyssey" by Stanley Kubrick in 1968, and the sentimental "Artificial Intelligence" by Steven Spielberg in 2001.

These days, artificial intelligence experts are working on ambitious projects such as data mining; knowledge representation; robotics; applications of the artificial intelligence methods in science, engineering, finance and healthcare; and the development of intelligent agents, autonomous systems, etc. (Artificial..., 2009). Experts are declaring, as many of their predecessors did, that the long-awaited "singularity" point is coming closer and closer, i.e. the moment when - and if - information technologies come to transcend human beings' physiological and mental limitations and finally overcome humans in productive decision making and effective problem solving (Kurzweil, 2005).

The overall progress, as well as many discouraging downfalls connected with the artificial intelligence studies which were carried out in the $20^{\text {th }}$ century, took place during Tikhomirov's lifespan. At the very beginning of his career, he felt as if he was at risk of losing his profession: while he carried out several experiments investigating the role of heuristic processes in thinking, and tried to make use of the theory of information in decision making (Tikhomirov, 1962; Tikhomirov, Poznyanskaya, 1966), he was not inclined to simulate thinking processes on computers. Tikhomirov's aim was to learn more about genuine psychological processes which remain quite far from being programmed, simulated and modeled, or even fully investigated. To his surprise, he found that not many psychologists seemed to invest their time to explore what constituted the particular nuances which differentiate human thinking processes from the cognitive operations performed by computers which are able to run advanced artificial intelligence projects (Tikhomirov, 1969; Tikhomirov, 1974).

The analytical and empirical studies that were oriented towards discovering this differentiation were the starting point for Tikhomirov's work in the psychology of computerization. His experiments in the psychology of thinking were concentrated on regulative functioning of emotions and motives, the genesis and dynamics of meanings and personal meanings, processes of goal-setting and sense-formation, etc. (Tikhomirov, 1969; Tikhomirov, 1983; Tikhomirov, 1988). This paper is not dedicated to discussing the particular details of Tikhomirov's work in the psychology of thinking. The paper's aim is to discuss Tikhomirov's suggestion that there should be a psychology of computerization and the ways in which this discipline transformed into cyber-psychology, or the psychology of Internet (up to now, both terms are being widely used, and we are not going to prefer one to the other). 
The suggestion to develop the psychology of computerization involves a set of ideas which characterize the particular scientific background of psychological studies which accompany the emerging information and communication technologies. Regretfully, several attempts, including those done by Tikhomirov and his colleagues (Tikhomirov, 1985; Tikhomirov, Babaeva, \& Voiskounsky, 1986), to give rise to prospective research fields such as computer-mediated communication (CMC), and human-computer interaction (HCI), also known as computer-human interaction (CHI), failed in Russia. We have mentioned in previous publications (Voiskounsky, 2008a; Voiskounsky, 2008b; Voiskounsky, 2013) that the suggested psychology of computerization has happened to have no reasonable counterpart in Russia. It has also not been developed in competitive contexts, and due to these reasons, one could be led to conclude that the discipline is a bit too broadly defined. Elsewhere $\mathrm{HCI} / \mathrm{CHI}$ is a well-developed and respectable field of knowledge, but in Russia there is no such a discipline: no departments dedicated to the subject in colleges and universities, no periodicals, original manuals or text-books, and only a few professionals in the field, in which no academic degrees have been issued (Voiskounsky, 2008a; Voiskounsky, 2013). Had this discipline been developed in Russia as it is being developed globally, some plans to nurture such a discipline which Tikhomirov had planned for the psychology of computerization might have additionally been applied to the HCI/CHI field. "Man-computer systems and not artificial intelligence represent, from our point of view, the future of computerization" (Tikhomirov, 1974, p. 379).

Within the psychology of computerization, Tikhomirov and his colleagues and disciples studied psychological specifics (in emotional regulation, motivation, goal-setting hierarchies, personality traits, locomotor operations, decision making, etc.) inherent to using computers and information systems, and compared them to non-computerized activities. These studies were involved in monitoring diverse types of behavior, including (but not limited to) engineering and design, planning in economics and accounting, software development, systems control, playing intellectual games, expertise in psychological diagnostics, training using simulators, etc. Some of these studies are discussed in more details in the other articles in the current issue.

\section{The impact of information technologies on psychological processes as a problem area of cyberpsychology}

As was mentioned earlier, while the need to differentiate the inherently human modes of cognitive performance from the specific operations related to the artificial intelligence partly lost its importance; Tikhomirov's studies of the impact of computers (or in general: information and communication technologies) on human psychological processes is currently of first-order significance.

The very notion of the 'psychology of computerization' nowadays sounds like something extremely global, this notion lost its uniqueness since almost every human type of behavior (such as cognition, working at an office or in industry, interaction, shopping, recreation and game playing, the exchange of verbal, acoustic and visual messages, etc.) has been computerized and is most often performed via the Internet. When Tikhomirov introduced the concept of a 'psychology of com- 
puterization', the availability of computers as instruments was limited to a narrow group of specialists. These included software developers, military personnel, and more infrequently, engineers, economists and scientists (Chelovek i computer, 1972; Chelovek i EVM, 1973; Tikhomirov, 1981; Tikhomirov, 1983). Three or four decades ago it was hard to foresee the perspectives which resulted in the presentday miniaturization and availability of computers, including desktop machines, notebooks, tablets and gadgets such as computerized smartphones. Additionally, by introducing the new notion and field of knowledge, Tikhomirov was fully referring to his methodology of the psychology of thinking; again, computerization is not currently limited to cognitive applications. Thus, we need to conclude that the notion of a 'psychology of computerization' has only a scant chance of being accepted and widely implemented in the $21^{\text {st }}$ century.

The other point which was equally important for Tikhomirov has experienced a much better fate. We suggest that in Russia, this very point has smoothly transformed into a contemporary field of study: cyberpsychology, also known as psychology of Internet. Tikhomirov himself called this sphere of work "the psychological consequences of computerization" (Tikhomirov, 1981). Cyberpsychology, or the psychology of the Internet, originates from, and benefits from, these origins; it also borrows from all the traditional psychological disciplines such as instructional, social, cognitive, clinical, organizational, differential, and developmental psychology as well as some newer disciplines such as ethnic or gender psychology, psycholinguistics, etc. Additionally, cyberpsychology often embraces studies done within non-psychological fields such as computer science and human-computer interaction, communication or media science. Just to mention, the first paper in Russia to present a pioneering study referring to the would-be psychology of Internet, or cyberpsychology (the terminology differed a lot from what we use now) described particular psychological aspects of computer mediated modes of interaction (Tikhomirov, Babaeva, \& Voiskounsky, 1986). The stages of development and the current status of cyberpsychology, or the psychology of Internet, in Russia are presented in diverse sources, including several papers in English (Voiskounsky, 2008b; Voiskounsky, 2012).

The Psychology of the Internet, or cyberpsychology, may be defined as a field of research and practice within psychology which deals with the ways human beings use Internet-related services; these services mediate socializing within diverse groups, computer networking and interaction, cognition, work, shopping, and entertainment including game playing, the downloading/uploading and exchange of videos, photos and music, as well as gambling, etc. (Voiskounsky, 2013). It is easy to notice that cyberpsychology, or the psychology of Internet, neighbors traditional disciplines within psychology; at the same time, dozens of totally new activities as well as totally new modes of performing well-known activities give reasonable grounds to consider cyberpsychology, or the psychology of the Internet, a new psychological discipline (Voiskounsky, 2012; Voiskounsky, 2013).

Tikhomirov's work on the psychology of computerization heavily made use of A.N. Leontiev's activity theory (Tikhomirov, 1969; Tikhomirov, 1999), and at the same time, the cultural-historic theory of psychological development (Tikhomirov, 1974) originated by L.S. Vygotsky (Vygotsky, 1962; 1978). We believe that the Vygotskian perspective is among the most promising in cyberpsychology, or 
the psychology of the Internet. Indeed, many research projects have been carried out within this paradigm (Arestova, Babanin, \& Voiskounsky, 1999; Voiskounsky, 2012). Among the newer theoretical approaches, that of positive psychology (Seligman, Csikszentmihalyi, 2000) has been shown to be promising and useful within the psychology of Internet, or cyberpsychology, namely the two well-developed theoretical aspects of positive psychology: self-determination theory (Przybylski et al., 2009; Przybylski et al., 2012) and the theory of flow experience (Voiskounsky, 2008c).

To make it shorter, in the current paper we will not go into details about positive psychology being a research paradigm in cyberpsychology, or the psychology of Internet. The use of the Vygotsky theory as a research paradigm, on the contrary, is worth of at least a brief discussion. The investigation of mediated forms of behavior is traditional for the Vygotskian approach. In the cultural psychology theory, it is emphasized that the higher mental processes have a social origin, their development is based on joint child-adult actions (especially within the zone of proximal development) and interpersonal communication, and presumably on mediated forms of behavior. Within this theory, mediation is fundamental since it includes acquiring and using instruments: material tools, signs, and semiotic systems. Genuine human forms of behavior are mediated by culture-related sign systems. The use of computer facilities and the Internet cannot be interpreted other than a mediation of cognition, entertainments and interactions, as well as all the other numerous aforementioned human needs. That means the analysis Tikhomirov conducted decades ago (Tikhomirov, 1974; Tikhomirov, 1988) was correct and the psychology of the Internet, or cyberpsychology, may develop fruitfully under the Vygotskian methodology.

Cyberpsychology has been developing in Russia in different ways (Voiskounsky, 2008c; Voiskounsky, 2012); the one that grows from the Tikhomirov's suggestion to initiate the study of the psychology of computerization is among the major ones. Within this range of studies, numerous research projects have been and are being done. Even when restricting ourselves exclusively to publications in English, we may mention studies in which the representatives of the new types of communities were the participants, such as computer hackers or gamers. Empirical studies of gamers' knowledge and motivational patterns have been conducted (Voiskounsky, Mitina, \& Avetisova, 2004; Voiskounsky, Mitina, \& Avetisova, 2005; Voiskounsky, Mitina, \& Avetisova, 2012) as well as hackers' motivations (Voiskounsky, Smyslova, 2003; Smyslova, Voiskounsky, \& Petrenko, 2008), and new trends in the moral development of the digital natives' generations (Voiskounsky, 2004). Additionally, studies have been conducted on the current extension of psychological dependencies, i.e. Internet addictions as an example of technological addictions have been analyzed as well (Voiskounsky, 2007; Voiskounsky, 2010). This line of studies had its origins in Tikhomirov's keen suggestion: psychologists should investigate various psychological consequences of the advance and use of information and communication technologies (Tikhomirov, 1974; Tikhomirov, 1981).

\section{Acknowledgements}

Supported by the Russian Foundation for Basic Research, project № 12-06-00281 


\section{References}

Ackoff, R., Emery, F. E. (1972). On Purposeful Systems. Aldine-Atherton: Chicago.

Arestova, O., Babanin, L., \& Voiskounsky, A. (1999) Psychological Research of Computer-Mediated Communication in Russia. Behaviour \& Information Technology, 18(2), 141-147. doi: 10.1080/014492999119174

Artificial Intelligence. An International Perspective. (2009) M. Bramer (Ed.). Berlin, Heidelberg, New York: Springer.

Ashby, W.R. (1956) An Introduction to Cybernetics. L.: Chapman \& Hall.

Bertalanffy, L. von (1950) An Outline of General System Theory. British Journal for the Philosophy of Science, 1, 114-129.

Chelovek i Komputer (1972) [Man and Computer]. O.K. Tikhomirov (Ed.). Moscow University Press.

Chelovek i EVM (1973) [Man and Electronic Machine]. O.K. Tikhomirov (Ed.). Moscow: Ekonomika.

Chomsky, N. (1957) Syntactic Structures. The Hague: Mouton.

Chomsky, N. (1959). A Review of B.F. Skinner's Verbal Behavior. Language, 35(1), 26-58. doi: $10.2307 / 411334$

Computers and Thought (1963). E.A. Feigenbaum, J. Feldman (Eds.). New York: McGraw-Hill.

Kurzweil, R. (2005). The Singularity is Near. New York: Penguin Books.

Lindsay, P.H., Norman, D.A. (1972). Human Information Processing. An Introduction to Psychology. New York \& London: Academic Press.

McCarthy, J., Minsky, M.L., Rochester, N., \& Shannon, C.E. (1955) A Proposal for the Dartmouth Summer Research Project on Artificial Intelligence. AI Magazine, 27(4), 12-14.

Miller, G.A., Galanter, E., \& Pribram, K.H. (1960). Plans and the Structure of Behavior. New York: Holt, Rinehart \& Winston. doi: 10.1037/10039-000

Neumann, J. von, Morgenstern, O. (1944). Theory of Games and Economic Behavior. Princeton University Press.

Newell, A., Shaw, J. C. \& Simon, H. (1958). Elements of a theory of human problem solving. Psychological Review, 65, 151-166. doi: 10.1037/h0048495

Newell, A., Simon, H. A. (1972). Human problem solving. Englewood Cliffs, NJ: Prentice-Hall

Przybylski, A. K., Weinstein, N., Murayama, K., Lynch, M. F., \& Ryan, R. M. (2012) The Ideal Self at Play: The Appeal of Video Games That Let You Be All You Can Be. Psychological Science, 23(1), 69-76. doi: 10.1177/0956797611418676

Przybylski, A. K., Weinstein, N., Ryan, R. M. \& Rigby, C. S. (2009). Having to versus Wanting to Play: Background and Consequences of Harmonious versus Obsessive Engagement in Video Games. Cyberpsychology \& Behavior, 12(5), 485-492. doi: 10.1089/cpb.2009.0083

Seligman, M. E. P., Csikszentmihalyi, M. (2000). Positive Psychology: An Introduction. American Psychologist, 55(1), 5-14. doi: 10.1037/0003-066X.55.1.5

Shannon, C. E., Weaver, W. (1949). The Mathematical Theory of Communication. University of Illinois Press.

Smyslova, O. V., Voiskounsky, A. E., \& Petrenko, V. F. (2008). Hackers' Motivation: Empirical Study. Psychology in Russia: State of the Art, 1, 224-238. doi: 10.11621/pir.2008.0015

Tikhomirov, O.K. (1959). Review of Verbal Behavior by B.F. Skinner. Word, 15(2), 362-367.

Tikhomirov, O.K. (1962) The solution of thinking problems as a probability process. Soviet Psychology and Psychiatry, 1(1), 21-30.

Tikhomirov, O. K. (1969). Struktura myslitelnoi deyatelnosti cheloveka [Structure of Human Thinking Activity]. Moscow University Press. 
Tikhomirov, O. K. (1974). Man and computer: The impact of computer technology on the development of psychological processes. In D.E. Olson (Ed.) Media and symbols: The forms of expression, communication, and education (pp. 357-382). University of Chicago Press.

Tikhomirov, O. K. (1981). The psychological consequences of computerization. In J.V. Wertsch (Ed.) The Concept of Activity in Soviet Psychology (pp. 256-278). Armonk, New York: M. E. Sharpe.

Tikhomirov, O. K. (1983). Informal heuristic principles of motivation and emotion in human problem solving. In R. Groner, M. Groner, \& W. Bischof (Eds.). Methods of Heuristics (pp. 153-170). New York, London: Lawrence Erlbaum Publ.

Tikhomirov, O. K. (1985). The psychological structure of the man-computer dialogue. Soviet Psychology, 23(4), 24-37.

Tikhomirov, O. K. (1988). Psychology of Thinking. Moscow: Progress Publ.

Tikhomirov, O. K. (1999). The theory of activity changed by information technology In Y. Engeström, R. Miettinen, \& R.-L. Punamäki (Eds). Perspectives on activity theory. Learning in doing: Social, cognitive, and computational perspectives (pp. 347-359). New York, NY: Cambridge University Press. doi: 10.1017/CBO9780511812774.023

Tikhomirov O. K., Babaeva, Yu. D., \& Voiskounsky, A. Ye. (1986). Obschenie, oposredstvovannoye kompyuterom [Computer Mediated Communication] Vestnik Moskovskogo Universiteta. Seriya 14. Psikhologiya [Moscow University Psychology Bulletin], 3, 31-42.

Tikhomirov, O. K., Babanin, L. N. (1986). EVM i novye problemy psikhologii [Electronic Machines and New Problems in Psychology]. Moscow University Press.

Tikhomirov, O.K., Poznyanskaya, E.D. (1966) An investigation of visual search as a means of analyzing heuristics. Soviet Psychology, 5(2) 2-15.

Voiskounsky, A. (2004). Current problems of moral research and education in the IT environment. In K. Morgan, C. A. Brebbia, J. Sanchez, \& A. Voiskounsky (Eds.), Human perspectives in the Internet society: Culture, psychology and gender (pp. 33-41). Southampton and Boston: WIT Press.

Voiskounsky, A. E. (2007). Two Types of Repetitive Experiences on the Internet. INTERFACE: The Journal of Education, Community and Values, 7(6). Retrieved from http://bcis.pacificu. edu/journal/2007/06/voiskounsky.php

Voiskounsky, A. Ye. (2008a). Ot psikhologii kompyuterizatsii k psikhologii Interneta [From Psychology of Computerization to Psychology of Internet]. Vestnik Moskovskogo Universiteta. Seriya 14. Psikhologiya [Moscow University Psychology Bulletin], 2, 140-153.

Voiskounsky, A. E. (2008b). Cyberpsychology and Computer-mediated Communication in Russia: Past, Present and Future. Russian Journal of Communication, 1(1), 78-94. doi: $10.1080 / 19409419.2008 .10756698$

Voiskounsky, A. E. (2008c). Flow Experience in Cyberspace: Current Studies and Perspectives. In A. Barak (Ed.), Psychological Aspects of Cyberspace: Theory, Research, Applications (pp. 70101). New York: Cambridge University Press. doi: 10.1017/CBO9780511813740.005

Voiskounsky, A. E. (2010). Internet Addiction in the Context of Positive Psychology. Psychology in Russia: State of the Art, 3, 541-549. doi: 10.11621/pir.2010.0026

Voiskounsky, A. (2012). The Origin and Current Status of Cyberpsychology in Russia. In: Zh. Yan (ed.). Encyclopedia of Cyber Behavior (pp. 1328-1338). Hershey, PA: IGI Global. doi: 10.4018/978-1-4666-0315-8.ch106

Voiskounsky, A. Ye. (2013). Perspektivy stanovleniya psikhologii Interneta [Perspectives of the Internet Psychology]. Psikhologicheskii Zhurnal [Psychological Journal], 34(3), 110-118.

Voiskounsky, A. E., Mitina, O. V., \& Avetisova, A. A. (2004). Playing online games: Flow experience. PsychNology Journal, 2(3), 259-281. Retrieved from

http://www.psychnology.org/PSYCHNOLOGY_JOURNAL_2_3_VOISKOUNSKY.pdf 
Voiskounsky, A. E., Mitina, O. V., \& Avetisova, A. A. (2005). Communicative patterns and flow experience of MUD players. International Journal of Advanced Media and Communication, 1(1), 5-25. doi: 10.1504/IJAMC.2005.007720

Voiskounsky, A., Mitina, O., \& Avetisova, A. (2012). Psychological Consequences of Video Gaming, as Structured by Players. In: J. Gackenback (Ed.).Video Games and Consciousness (pp. 46-68). New York: Nova Science Publishers.

Voiskounsky, A. E., \& Smyslova, O.V. (2003). Flow-based model of computer hackers' motivation. CyberPsychology \& Behavior, 6(3), 171-180. doi: 10.1089/109493103321640365

Vygotsky, L. S. (1962). Thought and language. Cambridge, Mass.: Harvard University Press. doi: 10.1037/11193-000

Vygotsky, L. S. (1978). Mind in society: The development of higher psychological processes. Cambridge, Mass.: Harvard University Press.

Wiener, N. (1948). Cybernetics or control and Communication in the Animal and the Machine. New York: John Wiley \& Sons.

Received: 08 September 2013

Accepted: 19 October 2013

Available online: 15 December 2013 